Acta Technologica Agriculturae 2

Nitra, Slovaca Universitas Agriculturae Nitriae, 2016, pp. 39-42

\title{
USING MODERN DIAGNOSTIC METHODS FOR TECHNOLOGICAL DISCIPLINE ASSESSMENT OF MAIZE SILAGE
}

\author{
Roman GÁLIK*, Štefan BOĎO, Lenka STAROŇOVÁ \\ Slovak University of Agriculture in Nitra, Slovak Republic
}

\begin{abstract}
The paper focuses on the analysis of compliance with the technological discipline in silage quality assessment based on sampling the silage wall using thermal imaging and penetrometer method for silage compaction. Experimental measurements were done in a selected company, which has built a silage trough with a capacity of $6,624 \mathrm{~m}^{3}$, in which the maize (hybrid KWS - KALIFF FAO 440) with a $36 \%$ solids content was ensiled. A thermal camera ThermoPro TM TP8S IR and cone penetrometer Eijkelkamp were used for measurements. The results obtained suggest that also undesirable heating was found in the sampling area, since the maximum temperature at some places in the depth of $0.5 \mathrm{~m}$ reached a temperature of $36.4^{\circ} \mathrm{C}$. According to regression and correlation analysis, we found direct linear relationship between penetration resistance and penetration depth in a $6 \mathrm{~m}$ and $1.5 \mathrm{~m}$ height $(R=0.938$ respectively $R=0.970)$.
\end{abstract}

Keywords: maize silage; penetration resistance; compaction; thermography; heating

Silage is preserved fodder which is characterized by low $\mathrm{pH}$ (3.7 to 5.0) according to dry matter content to form the organic acids, especially lactic acid, generated by fermentation of saccharides of low molecular weight (Doležal et al., 2006). If we want to harvest silage maize at the time with the highest nutritional value, to store and close silage clamps, it is necessary to well organize all operations (Bouška et al., 2006). It is required that silage troughs were filled as soon as possible, the ensiled mass must be air-tight, closed as soon as possible with plastic foil to create an anaerobic environment. Compression, influenced by the length of chop, significantly determines the quality of the fermentation process, the level of losses, preventing heat damage and silage hygienic quality (Doležal et al., 2006). Well compressed silage has a temperature comparable with air temperature; higher temperature is indicating incorrect compression - silage contains a lot of air. Prolonged temperature exposure, higher than $35^{\circ} \mathrm{C}$, creates irreversible bonds between saccharides and nitrogen substances, thereby reducing their fermentation.

Any interruption of silage or inadequate compaction is visually noticeable in the silage profile, e.g. by caramelized light brown to dark brown layer. In insufficiently compacted silage layers, as much air may be closed as sufficient for their getting mouldy. These mouldy deposits found in the silage profile cannot be practically removed (in comparison to the surface layer), and toxic mycotoxins are becoming part of fodder ration (Bouška et al., 2006). The proof of good silage management and subsequent handling is its temperature. It should never exceed $20^{\circ} \mathrm{C}$. If temperature exceeds $20^{\circ} \mathrm{C}$, it is not suitable for dairy cattle (even in summer).

Literature sources indicate that the self-heating of maize silage to $30{ }^{\circ} \mathrm{C}$ increases the losses caused by anaerobic fermentation of silage by $1.7 \%$ of dry matter per day. As prevention from undesirable heating, it is necessary to follow the technological discipline of silage (filling rate, application of additives, mass compaction, rate and covering of silage troughs) (Rajčáková, 2008).

The main observed problems are residues after milling and residues of air containing silage pushed back to the silage wall. Thus layered material begins to warm up, which means nutrient losses. These losses are 3\% for each $10{ }^{\circ} \mathrm{C}$ temperature increase per day (http://www.zea.cz/ vyziva-zvirat/lze-vyrabet-mleko-levneji-dil-vii/).

The thermal camera is used for detecting the temperature increase, silage quality and problems of silage wall, which at first sight upon arrival in the silo is not visible (http://www. zea.cz/konzervanty/termokamera-v-jame/). According to Reszler (2010), an infrared thermometer is more affordable.

The paper is focused on the analysis of compliance with the technological discipline in silage quality assessment based on sampling the silage wall using thermal imaging and penetrometer method for silage compaction.

\section{Material and methods}

Experimental measurements were done in the selected company, which has built a silage trough with a capacity of $6,624 \mathrm{~m}^{3}$, in which the maize (hybrid KWS - KALIFF FAO 440) with the $36 \%$ solids content was ensiled.

Cutting work was done with a harvester CLAAS JAGUAR 850 , and compacting was done with heavy weights based on railway wagon wheels. After compacting, the silage trough was hermetically closed with two silage foils and loaded with old tyres.

Measurements were done just before removing the fodder (24 hours after last removing, because the dairy 


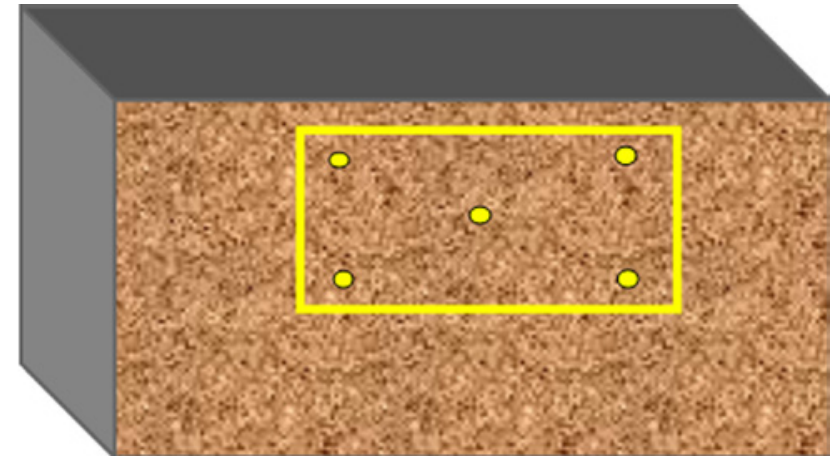

Figure 1 Marked boundaries of monitoring points on the sampling silage wall

cattle is fed once per day), and immediately after removing the fodder. Silage clamps are used in farm for removing the fodder. A metal frame with the dimensions $1.0 \times 0.5 \mathrm{~m}$ was prepared before the measurement. The frame was installed into the silage where temperature was measured by using the thermal camera. The average surface temperature and minimum respectively maximum temperature was measured in the selected area.

The following places in the silage trough were measured and evaluated:

- Fodder surface after removing the foil (height 6 m) before removal.

- Sampling silage wall (height $1.5 \mathrm{~m}$ ) - at a depth of $0.5 \mathrm{~m}$ after removal.

\section{Measuring device and processing of thermographs}

The thermal imaging camera ThermoPro TM TP8S IR is a high-quality equipment. Temperature profiles were evaluated using special software.

\section{Measurement of silage compaction with penetrometer method}

Silage penetration resistance (compaction) was measured with using the cone penetrometer. The working principle of the cone penetrometer is to press the metal cone with the ground area $1 \mathrm{~cm}^{2}$ and angle $60^{\circ}$ perpendicular to the measured surface (velocity $3 \mathrm{~cm} \cdot \mathrm{s}^{-1}$ ), with using the same pressure on both handles. Penetrologger's measuring range is $0-10 \mathrm{MPa}$. During measurements, penetration depth is recorded by an ultrasonic sensor. The maximum force is

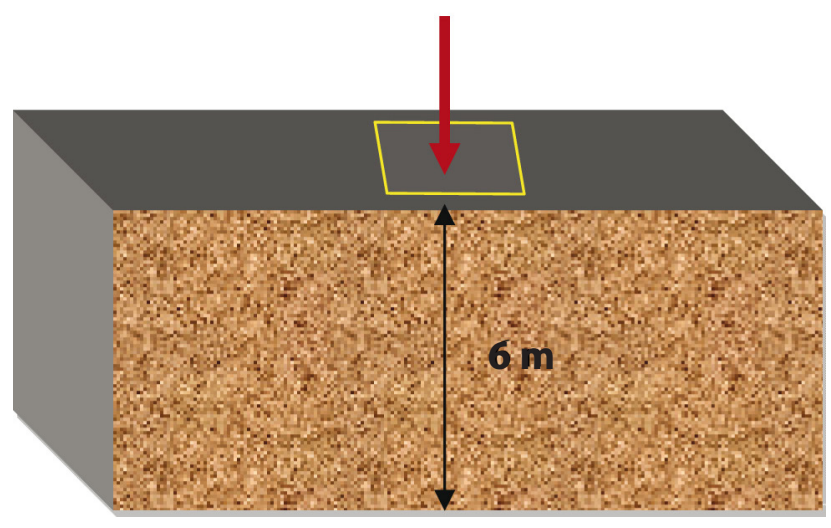

Figure 2 Measured area before fodder removal
$1,000 \mathrm{~N}$ and the resolution of force is $1 \mathrm{~N}$. The communication between the penetrometer and the computer is provided with communication ports (https://en.eijkelkamp.com/ products/field-measurement-equipment/penetrologgerset-a.html).

In each enclosed area with the dimensions $1.0 \mathrm{~m} \times$ $0.5 \mathrm{~m}, 5$ penetrations had been measured and then average values for each measured area (Figure 1) have been calculated. Experimental measurements were performed in the direction identical to the direction of fodder compression. The results were evaluated with regression and correlation analysis. A similar method was also used for determination of winter wheat straw bales compression (Korenko et al., 2013).

The penetration images were made of measured values. The peaks of curves could be read at a depth of $35 \mathrm{~cm}$. The measurements were carried out in winter when the outside air temperature was $2{ }^{\circ} \mathrm{C}$ and relative humidity $55 \%$.

\section{Results and discussion}

A) Fodder surface after removing the foil (height $6 \mathrm{~m}$ ) penetration resistance was measured in the direction identical to the direction of fodder compression. Measurement was done before fodder removal (Figure 2).

Results show that the average temperature of measured area before removal was $-0.6{ }^{\circ} \mathrm{C}$, the minimum temperature was $-2.4^{\circ} \mathrm{C}$, and the maximum temperature was $5.1^{\circ} \mathrm{C}$ (Table 1).
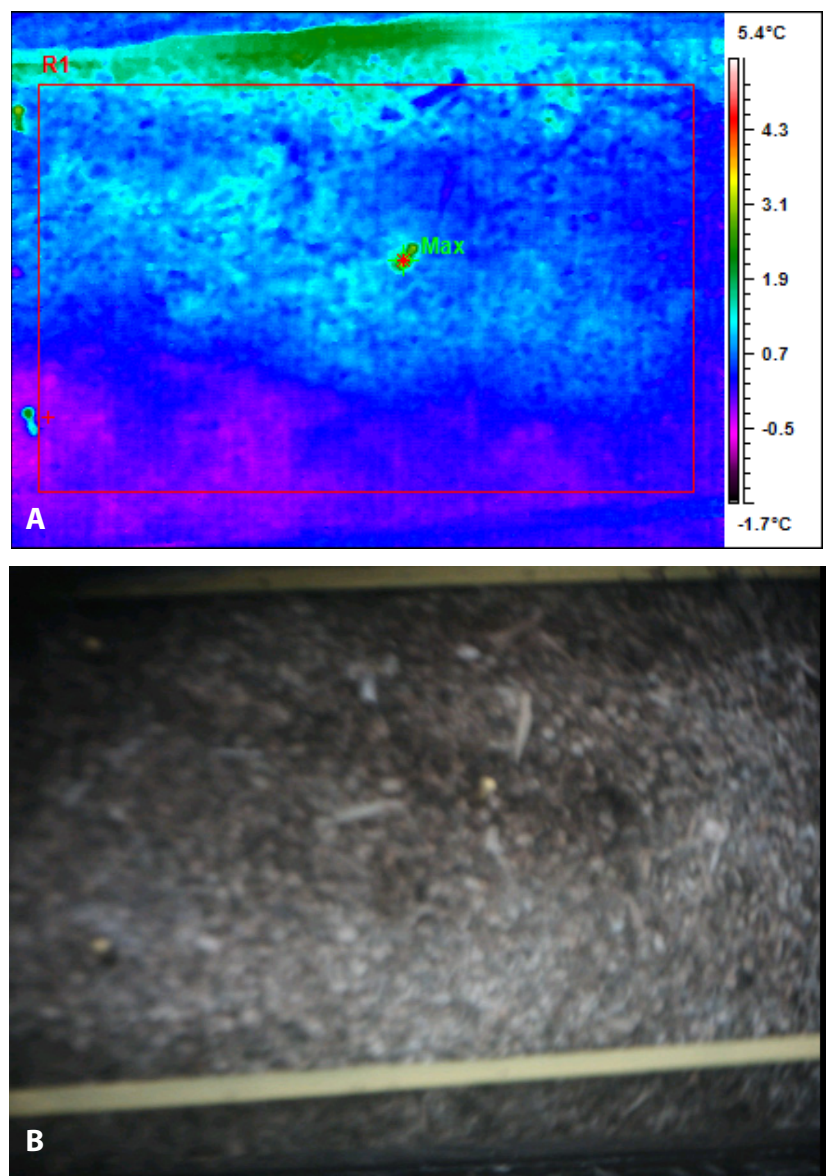

Figure $3 \quad$ a) Thermal image, b) Real image 
Table 1 Temperature of maize silage

\begin{tabular}{|l||c|c|}
\hline \multicolumn{1}{|l||}{ Parameter } & $\begin{array}{c}\text { Height } \mathbf{6 ~} \mathbf{~ m} \\
\text { value (before removal) }\end{array}$ & $\begin{array}{c}\text { Height } \mathbf{1 . 5} \mathbf{~ m} \\
\text { value (after removal) }\end{array}$ \\
\hline Average temperature & $-0.6^{\circ} \mathrm{C}$ & 28.0 \\
\hline Maximum temperature & $5.1^{\circ} \mathrm{C}$ & 36.4 \\
\hline Minimum temperature & $-2.4^{\circ} \mathrm{C}$ & 13.0 \\
\hline
\end{tabular}

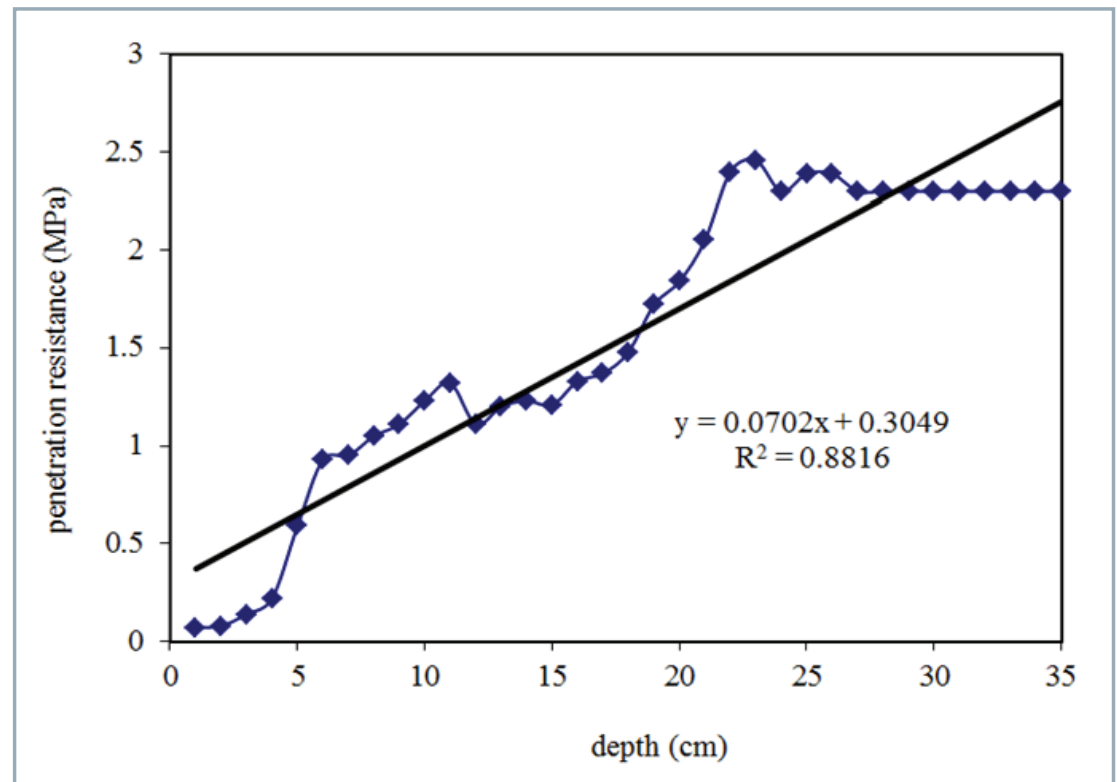

Figure 4 The relationship between penetration resistance and the depth of cone rod penetration

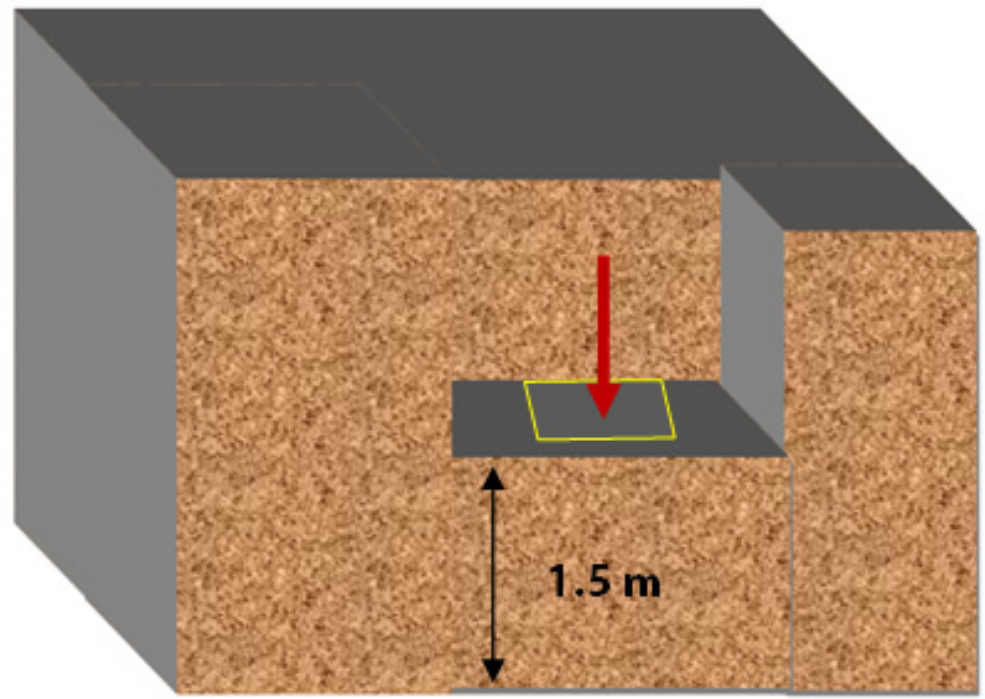

Figure $5 \quad$ Measured area after fodder removal

Figure 4 shows that there was an increase in the average values of penetration resistance $(2.46 \mathrm{MPa})$ to a deph of $23 \mathrm{~cm}$. Regression coefficient $R(0.938)$ is interpreted as a direct linear relationship between penetration resistance and the depth of cone rod penetration into the silage mass. The coefficient of determination $R^{2}(0.88)$ indicates that $88 \%$ of penetration resistance variability depends on depth. The $F$ significance determines the model suitability: the value is below (7.53E-17) the significance level (0.05), the model has been selected properly, and it is suitable for explaining the dependence. The model equation is in the form $y=0.30+0.07 x$. The $P$-value (7.53E-17) was below $\alpha$ (0.05), which means that regression coefficient is statistically significant. When the depth of cone rod penetration into the ensiled mass increases by about $1 \mathrm{~cm}$, penetration resistance will increase by about 0.07 MPa.

B) Sampling silage area (height $1.5 \mathrm{~m}$ ) - penetration resistance was measured in the direction identical to the direction of fodder compression. Measurement was done after fodder removal (Figure 5).

Obtained results indicate that the average temperature of the measured area after fodder removal was $28.0^{\circ} \mathrm{C}$, the minimum temperature was $13.0^{\circ} \mathrm{C}$, and the maximum temperature was $36.4{ }^{\circ} \mathrm{C}$ (Table 1). The increase of average values of penetration resistance (3.88 $\mathrm{MPa}$ ) was monitored into the depth of $35 \mathrm{~cm}$ (Figure 7).

Regression coefficient $R$ (0.970) shows the linear regression between penetration resistance and the depth of cone rod penetration into the silage mass. The coefficient of determination $R^{2}$ (0.94) indicates that $94 \%$ penetration resistance variability depends on depth.

The $F$ significance determines the model suitability: the value (6.09 E-22) was below (0.05), the model has been selected properly, and it is suitable for explaining the dependence. The model equation is in the form $y=0.49+0.09 x$. The $P$-value $(6.09 \mathrm{E}-22)$ was below a (0.05), which means that regression coefficient is statistically significant. The model implies that when the depth of cone rod penetration into the ensiled mass increases by about $1 \mathrm{~cm}$, penetration resistance will increase by about 0.09 MPa.

The study presents the possibilities of using modern diagnostic methods for heating detection, primarily because of insufficient compaction. Incorrectly compacted silage due to the presence of air is more prone to undesirable type of fermentation, loweraerobicfermentation and secondary fermentation (Rajčáková, 2007). A temperature increase of $15^{\circ} \mathrm{C}$ corresponds to $1.5 \%$ netto energy loss per day (http://www.schaumann. cz/ke-stazeni/produktove-letaky/ prednaska-bioplyn-schaumann.pdf). 

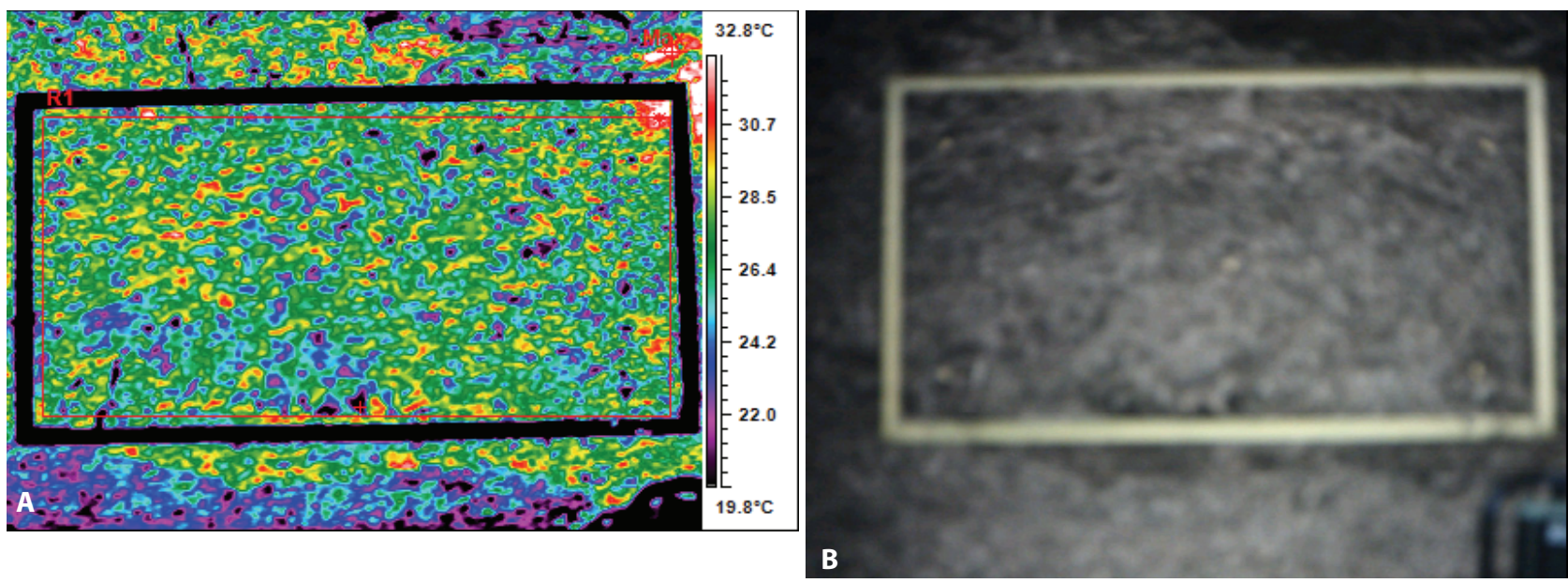

Figure 6 a) Thermal image, b) Real image

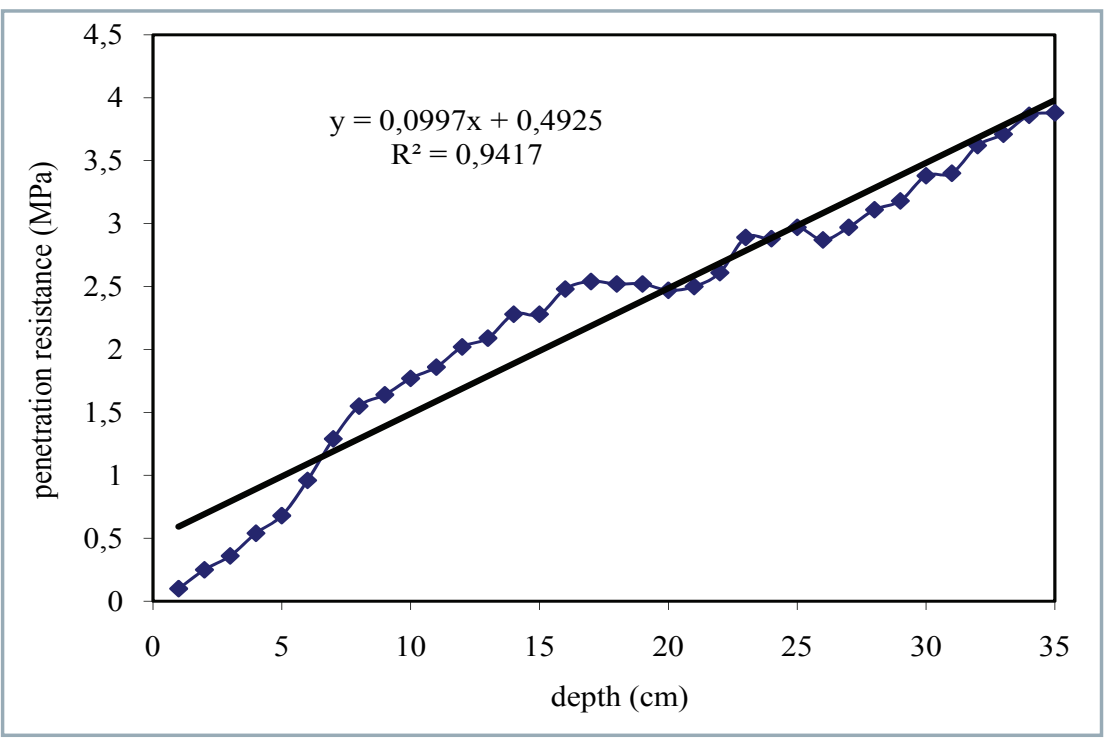

Figure 7 The relationship between penetration resistance and the depth of cone rod penetration at the height of $1.5 \mathrm{~m}$

\section{Conclusion}

The paper summarises the importance of compliance with the technological discipline for silage. The obtained results show the following:

- Places with undesirable heating were detected in the sampling silage area because the maximum temperature in the depth of $0.5 \mathrm{~m}$ reached $36.4{ }^{\circ} \mathrm{C}$ - that is describing the insufficient silage mass compaction;

- The penetration resistance of maize silage measured before removal in the direction of compression in the height $6 \mathrm{~m}$ reached the maximum in the depth of $23 \mathrm{~cm}(2.46 \mathrm{MPa})$ and at the height of $1.5 \mathrm{~m}$ reached the maximum value in the depth of $35 \mathrm{~cm}$ (3.88 MPa);

- Using the regression and correlation, we observed high linear regression
DÔLEŽITÁ je technologická disciplína Niektoré biologické a technologické aspekty výroby kvalitných kukuričných siláží [cit. 2015-02-17]. Available at: http:// biom.cz/cz/zpravy-z-tisku/dolezitaje-technologicka-disciplina-niektorebiologicke-a-technologicke-aspektyvyroby-kvalitnych-kukuricnych-silazi

EIJKELKAMP. Agrisearch equipment [cit. 201502-17]. Available at: https://en.eijkelkamp. $\mathrm{com} / \mathrm{products} /$ field-measurementequipment/penetrologger-set-a.html

LZE vyrábět mléko levněji? (Díl VII.) [cit. 2015-02-17]. Available at: http://www.zea.cz/vyziva-zvirat/ Ize-vyrabet-mleko-levneji-dil-vii/

KORENKO, M. - ŽITŇÁK, M. - MACÁK, M. 2013. Transport efficiency of straw bales for energy purposes. In Trends in Agricultural Engineering 2013. Prague: Czech University of Life Sciences Prague 2013, pp. 335-338. ISBN 978-80-123-2388-9.

RESZLER, G. 2010. Dojnica je v prvom rade prežúvavec. In Slovenský chov, vol. 15, 2010, no. 7, pp. 37-39.

RAJČÁKOVÁ, L.. 2007. Silážovania z hladiska výživnej hodnoty kukuričnej siláže. In Naše pole, vol. 11, 2007, pp. 54-55.

RAJČÁKOVÁ, Ł. 2008. Zásady silážovania kukurice. In Naše pole, vol. 12, 2008, no. 9, pp. 50-51.

TERMOKAMERA v jámě [cit. 2015-0217]. Available at: http://www.zea.cz/ konzervanty/termokamera-v-jame/

TŮMOVÁ, Z. 2014. Využitie termografickej metódy na odhal'ovanie zahrievania siláže z dôvodu nedostatočného utlačenia : diploma thesis. Nitra : SPU, 2014. 76 pp.

WINKELMANN, J. Príprava siláží z energetických rostlin pro bioplynové stanice, pro dosažení optimální produkce bioplynu [cit. 2015-02-17]. Available at: http://www.schaumann.cz/ke-stazeni/ produktove-letaky/prednaska-bioplynschaumann.pdf 